\title{
Assessment of Glyphosate and Quizalofop Mediated Toxicity to Greengram [Vigna radiata (L.) Wilczek], Stress Abatement and Growth Promotion by Herbicide Tolerant Bradyrhizobium and Pseudomonas species
}

\author{
Mohammad Shahid" and Mohammad Saghir Khan
}

\author{
Department of Agricultural Microbiology, Faculty of Agricultural Sciences, \\ Aligarh Muslim University, Aligarh-202002, Uttar Pradesh, India \\ *Corresponding author
}

\begin{tabular}{|c|c|}
\hline & A B S T R A C T \\
\hline & \multirow{6}{*}{$\begin{array}{l}\text { Continued and widespread use of herbicides for controlling weeds and indirectly } \\
\text { enhancing crop production often results in reduction in soil fertility and via food chain, } \\
\text { human health. Realizing this threat, herbicide tolerant plant growth promoting } \\
\text { rhizobacterial strains were isolated and identified. Of the total } 40 \text { bacterial strains, } \\
\text { Bradyrhizobium sp. strain R5 and Pseudomonas sp. strain PS6 tolerated } 3200 \text { and } 800 \mu \mathrm{g} \\
\mathrm{ml}^{-1} \text { ofglyphosate and Quizalofop P ethyl, respectively. Bradyrhizobium sp. strain R5 and } \\
\text { Pseudomonas sp. strain PS6 produced indoleacetic acid, exopolysaccharides, siderophores, } \\
\text { ammonia and solubilized inorganic P even in the presence of herbicides. Scanning electron } \\
\text { microscopic and CLSM images revealed a clear toxicity of herbicides to bacterial cells. } \\
\text { The toxicity of herbicides to greengram plants increased with increasing rates of } \\
\text { glyphosate and quizalofop. The herbicide tolerant Bradyrhizobium strain R5 and } \\
\text { Pseudomonas sp. strain PS6 when used with herbicide, considerably reduced toxicity to } \\
\text { greengram plants. For example, Bradyrhizobium strain R5 significantly increased the } \\
\text { nodule number, nodule dry mass, root and shoot length, root and shoot weight and total } \\
\text { chlorophyll content by } 10,333 \text {, } 16,68,23 \text { and } 6 \% \text { respectively, whereas, inoculation of } \\
\text { Pseudomonas sp. strain PS6 enhanced the measured parameters by } 2,7,3 \text {, } 12,25,22 \text { and } \\
20 \% \text {, respectively, as compared to the plants grown solely with } 1444 \mu \text { kg }{ }^{-1} \text { of } \\
\text { glyphosate. Among the two bacterial strains, Bradyrhizobium R5 showed better results } \\
\text { under identical herbicide stress as compared to the Pseudomonas PS6. In general, the } \\
\text { present findings suggest that both Bradyrhizobium sp. strain R5 and Pseudomonas sp. } \\
\text { strain PS6 could be exploited as an efficient microbial inoculant to increase the } \\
\text { productivity of greengram while reducing the toxicity of glyphosate and quizalofop. }\end{array}$} \\
\hline Keywor & \\
\hline $\begin{array}{l}\text { Green } \\
\text { Herbic } \\
\text { PGPR } \\
\text { Bioren } \\
\text { Growt }\end{array}$ & \\
\hline Artic & \\
\hline & \\
\hline & \\
\hline
\end{tabular}

\section{Introduction}

Environmental pollution due to wide spread use of agrochemicals is a major global threat to the sustainability of agro-ecosystems. Among various agrochemicals applied in agricultural practices, the intensive and uncontrolled use of herbicides over the years has caused serious problems (Ozkara et al.,
2016). The productivity of legumes on the other hand often suffers from weed competition. And hence, to control weeds and consequently to enhance crop production, herbicides are applied consistently. Among legumes, greengram is known for its detoxification activities and is used to refresh 
mentality, alleviate heat stroke, and reduce swelling in the summer (Tang et al., 2014). Greengram is a highly nutritious grain legume popularly cultivated in the tropics and forms a highly specific symbiosis with Bradyrhizobium sp. (Vigna). Like many legumes, greengram productivity often suffers from weed competition and therefore, requires chemical management (Jiddimani, 2017). Apart from affecting crops adversely at higher rates, herbicides also affect microbes (Zaller et al., 2016) indirectly, causing physiological changes and increasing enzymatic production (Usman et al., 2017) and /or leading eventually to the death of microorganisms (Prashar and Shah, 2016). Also, herbicides when applied had variable effects on greengram production (Gupta et al., 2017). These toxic problems however, can be circumvented by applying naturally occurring soil microflora. Among diverse microbial communities, plant growth promoting rhizobacteria (PGPR) have been reported to reduce the agrochemical toxicity by different mechanism (Azubuike et al., 2016) and has therefore, received considerable attention by the agronomists. Plant growth promoting rhizobacteria offers a viable and inexpensive option for safe detoxification/removal of agrochemicals from contaminated sites (Akbar and Sultan, 2016). Among PGPR, rhizobial species are reported to degrade many toxic pesticides including herbicides to non-toxic forms (Jaiswal et al., 2017), synthesize antifungal compounds (Gao et al., 2017), phytohormones (Porte, 2017) and siderophores (Kandel et al., 2017), and solubilize insoluble phosphate (Alori et al., 2017). Endowed with these properties, when rhizobia are applied, they have been found to enhance the growth of legumes in different ecological niches (Egamberdieva et al., 2017). The toxicity of herbicide to greengram plants on one hand and the ability of PGPR to circumvent herbicide toxicity on the other hand prompted us to undertake this study with the following specific objectives-(i) isolation and identification of rhizobacterial strains from root nodules of greengram plants and mustard rhizosphere (ii) assessment of herbicide tolerant potential of the isolated bacterial strains (iii) evaluation of plant growth promoting activity of herbicide tolerant strains exposed to herbicide stress and (iv) assay of toxic impact of herbicides and bioremediation potential of herbicide tolerant PGPR strains using greengram as a test legume.

\section{Materials and Methods}

\section{Isolation, characterization and identification of rhizobacterial strains}

A total of 40 rhizobacterial strains $(\mathrm{N}=20$ Bradyrhizobium, N=20 Pseudomonas) were recovered from the experimental fields of Faculty of Agricultural Sciences, Aligarh Muslim University, Aligarh $\left(27^{\circ} 29^{\prime}\right.$ latitude and $72^{\circ} 29^{\prime}$ longitude; western district of Uttar Pradesh, India) which had previous history of pesticide application for the last 7 years. Rhizobial strains $(\mathrm{N}=20)$ were isolated from nodules of greengram plants using yeast extract mannitol (YEM) medium $\left(\mathrm{g} \mathrm{L}^{-1}\right.$ : mannitol 10, $\mathrm{K}_{2} \mathrm{HPO}_{4} 0.5, \mathrm{MgSO}_{4} .7 \mathrm{H}_{2} \mathrm{O} 0.2$, $\mathrm{NaCl} 0.1$, yeast extract $1.0, \mathrm{CaCO}_{3} 1, \mathrm{pH} 7$ ) (Somasegaran and Hoben 1985). For this, pink colored and healthy nodules were surface sterilized (sodium hypochlorite $2.5 \%$ for $2 \mathrm{~min}$.), rinsed in $95 \%$ ethanol (v/v) and washed several times with distilled water and crushed gently in normal saline solutions (NSS). Nodule suspensions were serially diluted in NSS and $100 \mu \mathrm{L}$ of each diluent was spread plated on YEM agar medium containing $2.5 \%$ Congo red dye. Pseudomonas strains $(\mathrm{N}=20)$ were isolated from mustard rhizosphere using serial dilution assay. A-100 $\mu 1$ diluted soil suspension was spread plated on king's B agar medium ( $\mathrm{g}$ $\mathrm{L}^{-1}$ : Proteose peptone $20, \mathrm{~K}_{2} \mathrm{HPO}_{4} \quad 1.5$, 
$\mathrm{MgSO}_{4} .7 \mathrm{H}_{2} \mathrm{O} 1.5$, Agar $20 \mathrm{pH} 7.2 \pm 0.2$ ). The inoculated plates were incubated at $28 \pm 2{ }^{\circ} \mathrm{C}$ for 3 (Pseudomonas) to 5 days (rhizobia). Asingle bacterial colony from each plate was picked and streaked 4 times on the same medium to ascertain the purity of the cultures. The bacterial strains were maintained on their respective agar medium at $4^{\circ} \mathrm{C}$ until use. The rhizobial isolates were identified to genus level morphologically and biochemically (Table 1) following standard microbiological methods described in Bergey's Manual of Determinative Bacteriology (Holt et al., 1994) and host specific plant infection test (Somasegaran and Hoben, 1994).

\section{Assessment of bacterial strains for herbicide-tolerance}

The tolerance of rhizobacterial strains to herbicides was determined using commercial grade herbicides (Table 1); glyphosate and quizalofop-p-ethyl (Parijat Agrochemicals, New Delhi, India) by agar plate dilution method using minimal salt agar medium ( $\mathrm{g}$ $\mathrm{L}^{-1}: \mathrm{KH}_{2} \mathrm{PO}_{4} 1, \mathrm{~K}_{2} \mathrm{HPO}_{4} 1, \mathrm{NH}_{4} \mathrm{NO}_{3} 1$, $\mathrm{MgSO}_{4} .7 \mathrm{H}_{2} \mathrm{O} \quad 0.2, \quad \mathrm{CaCl}_{2} .2 \mathrm{H}_{2} \mathrm{O} \quad 0.02$, $\mathrm{FeSO}_{4} .7 \mathrm{H}_{2} \mathrm{O}$ 0.01, pH 6.5). The freshly prepared agar plates were amended individually with concentrations ranging from 0 to $6,400 \mu \mathrm{g} \mathrm{mL}^{-1}$ at two-fold dilution intervals for both glyphosate and quizalofopp-ethyl. The plates were spot inoculated with $10 \mu \mathrm{L}$ of $10^{8}$ cells $\mathrm{mL}^{-1}$ of bacterial strains and incubated at $28 \pm 2{ }^{\circ} \mathrm{C}$ for 3 days and the highest concentration of herbicides showing no inhibitory effect was defined as the maximum tolerance level (MTL).

\section{Assay of plant growth regulators under glyphosate and quizalofop stress}

Plant growth promoting activity of selected PGPR strains was assessed under both normal and herbicide stressed conditions. Among plant promoting substances, indole acetic acid
(IAA) was quantitatively assayed by spectrophotometric method (Gordon and Weber 1951) later modified by Brick et al., (1991). Bacterial strains believed to secrete IAA were grown in LB broth supplemented with $0,600,1200$ and $1800 \mu \mathrm{g} \mathrm{mL}$ glyphosate and $0,200,400$, and $600 \mu \mathrm{g} \mathrm{mL}^{-1}$ quizalofop P ethyl. A-100 ml of LB broth treated with $100 \mu \mathrm{g} \mathrm{ml} \mathrm{g}^{-1}$ tryptophan was inoculated with $1 \mathrm{~mL}\left(10^{8}\right.$ cells $\left.\mathrm{mL}^{-1}\right)$ each of Bradyrhizobium and Pseudomonas strains. The bioprimed LB broth was incubated at 28 $\pm 2^{\circ} \mathrm{C}$ for 5 days with moderate shaking at 125 $\mathrm{r} / \mathrm{m}$. Rhizobacterial cultures were removed at exponential growth phase and centrifuged at $5,433 \mathrm{~g}$ for $15 \mathrm{~min}$. An aliquot of $2 \mathrm{ml}$ supernatant was mixed with $100 \mu \mathrm{L}$ orthophosphoric acid and $4 \mathrm{ml}$ Salkowsky reagent $\left(2 \% \quad 0.5 \mathrm{M} \mathrm{FeCl}_{3}\right.$ in $35 \%$ perchloric acid) was added to it and incubated at $28 \pm 2{ }^{\circ} \mathrm{C}$ in darkness for $1 \mathrm{~h}$. The absorbance of pink color developed was read at $530 \mathrm{~nm}$. IAA concentration in the supernatant was determined using a calibration curve of pure IAA as a standard. Siderophores released by the bacterial strains were detected by $\mathrm{FeCl}_{3}$ test (Neiland, 1981).

Bacterial cultures were grown in NB supplemented with different concentrations of herbicides $\left(0,600,1200\right.$ and $1800 \mu \mathrm{g} \mathrm{mL}^{-1}$ glyphosate and 0, 200, 400 and $600 \mu \mathrm{g} \mathrm{mL}^{-1}$ quizalofop P ethyl) and incubated at $28 \pm 2{ }^{0} \mathrm{C}$ for 4 days. After incubation, cultures were centrifuged (3000 rpm) for $20 \mathrm{~min}$. One $\mathrm{ml}$ of supernatant was taken and $1 \mathrm{ml}$ of $2 \% \mathrm{FeCl}_{3}$ was added to each tube. Change in color from reddish brown to orange was observed. For exopolysaccharide (EPS) estimation, rhizobial strains were grown in $100 \mathrm{~mL}$ capacity flasks containing basal medium containing 5\% sucrose and different concentration of herbicides and incubated for 5 days at $28 \pm 2^{\circ} \mathrm{C}$ on rotary shaker. Culture broth was spun at $5,433 \times \mathrm{g}$ for $30 \mathrm{~min}$. and EPS was extracted using 3:1 ratio of chilled acetone. The 
precipitated EPS was repeatedly washed 3 times alternately with distilled water and acetone, transferred to a filter paper and weighed after overnight drying (Mody et al., 1989). Hydrogen cyanide (HCN) and ammonia production under herbicide stress was determined by the methods of Bakker and Schipper (1987) and Dye (1962), respectively.

The phosphate solubilization activity (PSA) was quantitatively estimated using liquid Pikovskaya medium amended with $0,1 \mathrm{X}, 2 \mathrm{X}$ and $3 \mathrm{X}$ concentration of glyphosate and quizalofop. The amount of solubilized $\mathrm{P}$ was evaluated by chlorostannous reduced molybdophosphoric acid blue method (King, 1932; Jackson, 1976). Each individual experiment was repeated three times.

\section{Cellular damage induced by herbicides under SEM and CLSM}

Cellular damage to the bacterial strains R5 and PS6 were observed under SEM using the method described by Saleem et al., (2017) after growing the cultures in nutrient broth $\left(\mathrm{gl}^{-1}\right.$ : peptone 10 ; beef extract $10 ; \mathrm{NaCl} 5$; $\mathrm{pH}=7$ ) treated with 1200 and $400 \mu \mathrm{g} \mathrm{ml-}{ }^{1}$ of glyphosate and quizalofop, respectively. Also, the toxicity of the herbicides to bacterial strains was validated under Confocal Laser Scanning Microscopy (CLSM).

\section{Seed inoculation, herbicide treatment and plant culture}

Healthy seeds of greengram (var. K851) were surface sterilized with $70 \%$ ethanol for 3 min.; $3 \%$ sodium hypochlorite $(\mathrm{NaOCl})$ for 3 min.; rinsed six times with sterile water and dried. Sterilized seeds were bacterized with Bradyrhizobium strain R5 and Pseudomonas sp. strain PS6, separately by soaking the seeds in liquid culture medium for $2 \mathrm{~h}$ using $10 \%$ gum arabic as sticker to maintain a bacterial load of $10^{8}$ cells seed ${ }^{-1}$. The un-inoculated sterilized seeds soaked in sterile water only was used as control. A-total of 10 uninoculated and inoculated seeds were sown in earthen pots $(25 \mathrm{~cm}$ high, $22 \mathrm{~cm}$ internal diameter) using $3 \mathrm{~kg}$ unsterilized soils (sandy clay loam, organic C $6.2 \mathrm{~g} \mathrm{~kg}^{-1}$, Kjeldahl N $0.75 \mathrm{~g} \mathrm{~kg}^{-1}$, Olsen P $16 \mathrm{mg} \mathrm{kg}^{-1}, \mathrm{pH} 7.2$ and water holding capacity $0.44 \mathrm{~mL} \mathrm{~g}^{-1}$, cation exchange capacity $11.7 \mathrm{cmol} \mathrm{kg}^{-1}$ and 5.1 cmol kg-1 anion exchange capacity). Pots were treated pre-sowing with 0 (control), 1444 (1X), 2888 (2X) and 4332 (3X) $\mu \mathrm{g}$ glyphosate $\mathrm{kg}^{-1}$ soil and 0 (control), 40 (1X), $80(2 \mathrm{X})$ and 120 (3X) $\mu \mathrm{g}$ quizalofop $\mathrm{p}$ ethyl $\mathrm{kg}^{-1}$ soil separately. Soils after adding the calculated concentration of each herbicide was mixed homogenously. Three pots for each treatment were arranged in a complete randomized design. Three plants were maintained in each pot 7 days after emergence. The pots were watered as and when required and maintained in an open field conditions.

\section{Measurement of biological characteristics of plants}

\section{Length, dry matter and symbiotic attribute}

Greengram plants grown in three pots for each treatment were uprooted and change in growth (length and height) of plants was recorded at 60 DAS. Plants detached at 60 DAS were dried at $80^{\circ} \mathrm{C}$ and dry biomass was determined. Plants removed at 60 days after seeding (DAS) were also used to score nodule numbers.

Roots were gently washed, and nodules were detached, counted, oven dried at $80^{\circ} \mathrm{C}$ and nodule dry mass were measured. Due to- (i) small size of experimental pots (ii) lodging problems of standing greengram plants and (iii) problem in maintaining adequate nutrients in pots, the plants were harvested before grain yield stage. 


\section{Total chlorophyll content}

Total chlorophyll content of fresh foliage was estimated by the method of Arnon (1949). For this, fresh leaves $(0.5 \mathrm{~g})$ were crushed in $20 \mathrm{ml}$ of $80 \%$ acetone. The extract was centrifuged at5000 r/min for $5 \mathrm{~min}$. Supernatant was taken and the volume was made $50 \mathrm{ml}$ with $80 \%$ acetone. Absorbance was read at 645 and $663 \mathrm{~nm}$ on UV vis-spectrophotometer.

Total chlorophyll content was calculated as:

Total chlorophyll $=\frac{\left[20.2 \times 0 . D_{645}+8.02 \times 0 . D_{663}\right] \times V}{1000 \times W}$

Where, $\mathrm{V}$ is the final volume of chlorophyll extraction in $80 \%$ acetone and $\mathrm{W}$ is the fresh weight of tissue extract.

\section{Effect of herbicides on root morphology of greengram (SEM study)}

The toxic and destructive impact of glyphosate and quizalofop on root morphology of greengram plants grown on soft agar plates treated with and without 1200 and $400 \mu \mathrm{g} \mathrm{ml}^{-1}$ of glyphosate and quizalofop, respectively, was monitored under JSM 6510 LV scanning electron microscope (JEOL, Japan) as described by Ahmed et al., (2017).

\section{Statistical analysis}

In vitro experiments were repeated three times and data were statistically analysed using Duncan's multiple range test (DMRT) at $5 \%$ probability level. Since the data of the measured parameters obtained were homogenous, they were pooled together and subjected to analysis of variance (ANOVA). The difference among treatment means was compared by high range statistical domain (HSD) using DMRT test. Plant based data were also analyzed by two-way ANOVA at $5 \%$ probability level.

\section{Results and Discussion}

Characterization and identification of herbicide tolerant rhizobacterial strains

In this study, the morphological and biochemical features of bacterial strains recovered from mustard rhizosphere and greengram nodules varied greatly (Table 2). Based on these properties, Gram negative strains R5 (from nodules of greengram) and PS6 (from mustard rhizosphere) were identified to genus level as Bradyrhizobium and Pseudomonas, respectively (Table 2). Also, the bacterial strains when grown on herbicide amended minimal salt agar plates showed significant tolerance to quizalofoppethyl, and glyphosate, which ranged between 800 to $3200 \mu \mathrm{g} \mathrm{ml}^{-1}$. Occurrence of tolerance or resistance to herbicides among PGPR herbicides is perhaps a unique feature which is regulated both genetically and physiologically. Hence, microorganisms that have developed resistance to pesticides are capable of frequently degrading them (Curutiu et al., 2017). Resistance against pesticides in general is attributed due to physiological changes that induce microbial metabolism to follow a new metabolic pathway that help organisms to bypass a biochemical reaction which could otherwise be inhibited by some specific pesticides (Bellinaso et al., 2003). Also, the resistance could be due to emergence of mutations inherited by successors of microbes (Herman et al., 2005). Since the minimal salt media used in our study to evaluate the MTL values of herbicide tolerant of both rhizobacterial strains (R5 and PS6) did not contain any C and $\mathrm{N}$ sources except the tested herbicides, it is inferred that both the strains might have utilized these herbicides amended in minimal salt agar medium as a sole energy source through a biodegradation process and hence, showed high tolerance levels against herbicides. Similarly, in other report, $P$. 
fluorescens tolerated higher level of herbicides like, Imazethapyr, 2,4-D and pendimethalin (Kurhade et al., 2016).

\section{Effect of herbicides on PGP activities of rhizobacterial strains}

\section{IAA, siderophores, HCN and ammonia}

The effect of herbicides on plant growth promoting rhizobacteria including nitrogen fixers (Nithyakalyani et al., 2016) and phosphate solubilizing microorganisms (Chandra et al., 2016) have been variable. Here, both R5 and PS6 strains displayed significant PGP activities and produced IAA, siderophores, $\mathrm{HCN}$ and $\mathrm{NH}_{3}$. It was observed that herbicides in general had deleterious effect which however, increased with increasing concentration of glyphosate and quizalofop-p ethyl. Of the different growth regulators, IAA produced by PGPR has been found to enhance the growth and other physiological activities of plants such as-(i) root morphogenesis and root elongation (ii) cell growth, division and symbiosis (iii) apical dominance and (iv) phototropism and geotropism seven in herbicide contaminated soils (Deinum et al., 2016).

Among the bacterial strains, Pseudomonas PS6 produced significantly more amount of IAA $(51.48 \mathrm{ug} / \mathrm{ml})$ as compared to Bradyrhizobium strain R5 (43.8 ug/ml). However, under herbicide stress the level of IAA was considerably reduced in both the strains. Comparing the effects of the herbicides, quizalofop-p-ethyl at two time more concentration, reduced the IAA secretion maximally by $70 \%$ in case of PS6. Glyphosate at the same rate showed least toxicity and decreased IAA by $55 \%$ in case of Bradyrhizobium R5 while and it was 36\%in case of Pseudomonas PS6 over untreated control (Table 3). In an identical experiment, Nityakalyani et al., (2016) observed similar results for Bradyrhizobium when grown in stress free medium. Reduction in IAA production by PGPR strains under herbicides stress has also been reported recently by Tripathi et al., (2015). Siderophores is yet another important microbial metabolite secreted by majority of bacteria (Sicairos, 2015) and fungi (Aziz et al., 2016). Siderophores synthesized by microbial communities' supply iron to plants when grown under iron-deficient conditions (Kurth et al., 2016). Also, the microbial siderophores for example pyoverdine produced by many Pseudomonas species has been reported to play an important role in the management of phytopathogens (Premachandra, 2016). Considering these, the siderophores production potential of BradyrhizobiumR5 andPseudomonasPS6 was evaluated in this study.

As the concentration of herbicides increased, it affected negatively the production of siderophores by both bacterial strains. Another important but indirect plant growth promoting activity of $\mathrm{HCN}$ production has been found to be a common trait of Pseudomonas and Bacillus (Thakur et al., 2017).Cyanide is a secondary metabolite of several microorganisms, which can be produced directly from glycine and cyanogenic glycosides (Rijavec and Lapanje, 2016).

Though the strains demonstrated significant production of HCN and ammonia, but at the highest concentration (3X) of herbicides, these activities were completely inhibited. Reduction in HCN and ammonia production by rhizobacterial strains under stressed environment is reported probably be due to the impairment of various metabolic activities (Azarmi et al., 2016). Similarly, inhibition in $\mathrm{HCN}$ and ammonia produced by rhizosphere microorganisms under stressed environment is reported (Rani and Kumar, 2017). 
Exopolysaccharide (EPS) production and phosphate solubilization

Exopolysaccharide is a major biochemical component which protects bacteria from harsher environment (Kaushal and Wani, 2016). In our study, Bradyrhizobium strain R5 and Pseudomonas strain PS6 produced considerable amounts of EPS both under herbicide free and stressed conditions. However, as the concentration of herbicides was increased, the quantity of EPS was decreased (Fig. 2). At the highest concentration of herbicides, the percent decrease in EPS by Bradyrhizobium strain R5 followed the order: quizalofop-p-ethyl (89) >glyphosate (56) while in case of strain Pseudomonas strain PS6, it was: quizalofopp-ethyl (81)>glyphosate (33).

Inorganic phosphate solubilization is yet another major PGP activity associated with PGPR that facilitate plant growth by supplying soluble $\mathrm{P}$ to plants. This $\mathrm{P}$ solubilizing activity of rhizobacteria is coupled to drop in $\mathrm{pH}$, which could be due to secretion of low molecular weight organic acids such as gluconic, $\alpha-2$ ketogluconic, oxalic, citric, acetic, malic and succinic acids etc. (Patel et al., 2015). In the present study, the amount of P-solubilized by the herbicide tolerant strains decreased with increasing concentration of herbicides. The maximum decrease in the P-solubilization was observed in Bradyrhizobium sp. R5 at quizalofop-pethyl, as compared to Pseudomonas sp. PS6 at all the concentrations tested. However, at the maximum concentration of herbicide added to media, the order of herbicide-toxicity in case of both strains (percent decline relative to control) was quizalofop-p-ethyl>glyphosate.

Similar production and reduction in phosphate solubilizing activities of bacterial strains under herbicides stress has been reported (Tripathi et al., 2015).
Evaluation of herbicide induced toxicity to bacterial strains under SEM and CLSM

After assessing the lethal effect of glyphosate and quizalofop on viable growth of both bacterial strains under in vitro conditions, the toxicity of herbicides to strains R5 and PS6 was evaluated further by SEM. The SEM images showed a dissimilar but un-ruptured bacterial cell when grown in the absence of herbicide (Fig. 1A and D). However, bacterial strains when grown in the presence of 1200 and $400 \mu \mathrm{g} \mathrm{ml}^{-1}$ of glyphosate and quizalofop, respectively, had damaged and disintegrated cell surface (Fig. 1B, C, E and F). The SEM analysis therefore, confirmed the herbicidal toxicity and validated the inhibitory effect of glyphosate and quizalofop observed under in vitro condition. To the best of our information, no similar reports on herbicidal toxicity to cellular damage of bacterial cells observed under SEM are available. CLSM images further validated the toxicity of herbicides resulting in increasing number of dead cells which increased with increasing concentrations of herbicides (data not shown). And hence, this is also perhaps the first report on herbicidal toxicity to agronomically important PGPR (Bradyrhizobium and Pseudomonas) observed under CLSM.

\section{Assessment of bioremediation potential of bacterial strains}

\section{Inoculation effects on length and dry biomass of plant organs}

The change in growth of plant organs (roots and shoots) of greengram plant grown in sandy clay loam soil treated with the recommended (1X), two (2X) and three (3X) times more of recommended rates of commercial grade herbicides (quizalofop-pethyl and glyphosate) varied at 60 DAS (Table 4). Generally, a progressive decline of variable magnitude was observed for both 
root and shoot length as the concentration of quizalofop-p-ethyl and glyphosate was increased from $1 \mathrm{X}$ to $3 \mathrm{X}$ in soil. Among herbicide, $4332 \mu \mathrm{g} / \mathrm{kg}$ soil of glyphosate displayed the most toxic and obvious effect and decreased root and shoot length by $34 \%$ $(5 \mathrm{~cm})$ and $37 \%(15 \mathrm{~cm})$, respectively while quizalofop at $120 \mu \mathrm{g} / \mathrm{kg}$ soil (3X) decreased root and shoot length by $44 \%(\mathrm{~cm})$ and $32 \%$ (cm), respectively, at 60 DAS. However, when used as inoculant, Bradyrhizobium and Pseudomonas reduced significantly the toxicity of herbicides. For example, Bradyrhizobium sp. R5 inoculated greengram plants grown in soils treated with $1 \mathrm{X}$ of quizalofop had $8 \%$ more shoot length relative to uninoculated and untreated control plants. While, Pseudomonas sp. PS6 increased the root and shoot length by $3 \%$ and $12 \%$ when plants were grown with normal rates of glyphosate in comparison to uninoculated, but glyphosate treated greengram plants.
The dry biomass accumulation in plant organs (roots and shoots) and whole plants grown in sandy clay loam soil consistently decreased with increasing concentrations of both herbicides. In general, all concentrations of quizalofop and glyphosate decreased the dry matter accumulation in root and shoots removed at 60 DAS relative to the control. Quizalofop and glyphosate at 3X maximally declined the dry biomass of roots by 37 and $24 \%$ and shoots by 40 and $70 \%$ at 60 DAS, respectively. In contrast, the bioinoculants in general reduced the phytotoxic effect of herbicides to greengram plants. For example, maximum growth promotory effect was recorded when Bradyrhizobium and Pseudomonas inoculated plants were grown in soils treated with normal rates of glyphosate and the total shoot dry biomass of greengram plant was increased by $23 \%$ and $10 \%$, respectively as compare to control at 60 DAS.

Table.1 Herbicides used in the present study

\begin{tabular}{|c|c|c|}
\hline \multirow[t]{2}{*}{ Characteristics } & \multicolumn{2}{|c|}{ Herbicide used } \\
\hline & Glyphosate & Quizalofop-ethyl \\
\hline Common name & Glyphosate & Quizalofop-ethyl \\
\hline Chemical name & $\mathrm{N}$-(phosphonomethyl) glycine & $\begin{array}{l}\text { (RS)-2-[4-6-chloroquinoxalin-2- } \\
\text { yloxy) phenoxy] propionate }\end{array}$ \\
\hline Chemical family & Organophosphorous & Quinoxaline \\
\hline Trade name & Round up & Targa \\
\hline Manufacturer & Monsanto, Excel & Nissan \\
\hline Molecular weight & 169.08 & 372.8 \\
\hline Empirical formula & $\mathrm{C}_{3} \mathrm{H}_{8} \mathrm{NO}_{5} \mathrm{P}$ & $\mathrm{C}_{19} \mathrm{H}_{17} \mathrm{ClN}_{2} \mathrm{O}_{4}$ \\
\hline Solubility & Water & Water, benzene, xylene etc. \\
\hline Melting point & $200{ }^{0} \mathrm{C}$ & $91.7{ }^{0} \mathrm{C}$ \\
\hline $\begin{array}{l}\text { Recommended Dose } \\
(\mu \mathrm{g} / \mathrm{kg})\end{array}$ & 1444 & 40 \\
\hline Structure & & \\
\hline
\end{tabular}


Table.2 Morphological and biochemical properties of bacterial strainsPS6 and R5

\begin{tabular}{|c|c|c|}
\hline Characteristics & Pseudomonas sp. strain PS6 & Bradyrhizobium sp. strain R5 \\
\hline Morphology & $\begin{array}{l}\text { Margin entire, mucoid and } \\
\text { dull green colony }\end{array}$ & $\begin{array}{l}\text { Irregular margin, transparent, slimy and } \\
\text { mucilaginous colony }\end{array}$ \\
\hline Gram reaction & -ve & -ve \\
\hline Shape & Short rods & Short rods \\
\hline \multicolumn{3}{|l|}{ Biochemical reactions } \\
\hline Citrate utilization & + & - \\
\hline Indole & - & - \\
\hline Methyl red & - & + \\
\hline Nitrate reduction & + & + \\
\hline Oxidase & - & + \\
\hline Voges Proskaur & - & - \\
\hline \multicolumn{3}{|l|}{ Carbohydrate utilization } \\
\hline Glucose & + & + \\
\hline Lactose & + & + \\
\hline Fructose & + & + \\
\hline Sucrose & + & + \\
\hline \multicolumn{3}{|l|}{ Hydrolysis } \\
\hline Starch & + & - \\
\hline Gelatin & + & + \\
\hline \multicolumn{3}{|c|}{ Tolerance to herbicides(MTL) } \\
\hline Glyphosate & $3200 \mu \mathrm{g} \mathrm{mL}$ & $3200 \mu \mathrm{g} \mathrm{mL}$ \\
\hline Quizalofop p ethyl & $800 \mu \mathrm{g} \mathrm{mL}$ & $800 \mu \mathrm{g} \mathrm{mL}$ \\
\hline
\end{tabular}

Table.3 Plant growth promoting activities of Bradyrhizobium strain R5 and Pseudomonas PS6 under glyphosate and quizalofop stress

\begin{tabular}{|c|c|c|c|c|c|c|c|c|}
\hline \multirow[t]{2}{*}{ Bacterial strains } & \multirow[t]{2}{*}{ Treatments } & \multirow{2}{*}{$\begin{array}{l}\text { Dose } \\
\text { rate } \\
(\mu \mathrm{g} / \mathrm{ml})\end{array}$} & \multicolumn{6}{|c|}{ Plant growth promoting substances } \\
\hline & & & $\begin{array}{l}\text { IAA } \\
(\mu \mathrm{g} / \mathrm{ml})\end{array}$ & $\begin{array}{l}\text { Siderophores } \\
\left(\mathrm{FeCl}_{3} \text { test }\right)\end{array}$ & HCN & Ammonia & $\begin{array}{l}\text { P solubilized } \\
(\mu \mathrm{g} / \mathrm{ml})\end{array}$ & EPS $(\mu \mathrm{g} / \mathrm{ml})$ \\
\hline \multirow{7}{*}{$\begin{array}{l}\text { Bradyrhizobium } \\
\text { sp. strain R5 }\end{array}$} & Control & 0 & $43.8 \pm 1.4 \mathrm{~b}$ & ++ & + & +++ & $4.6 \pm 0.4 c$ & $1.9 \pm 0.4 a$ \\
\hline & & 600 & $39.8 \pm 0.2 c$ & ++ & + & ++ & $3.5 \pm 0.4 \mathrm{~d}$ & $1.3 \pm 0.2 b$ \\
\hline & Glyphosate & 1200 & $32.7 \pm 0.6 \mathrm{e}$ & + & + & ++ & $2.8 \pm 0.2 \mathrm{fg}$ & $1.0 \pm 0.04 \mathrm{bcd}$ \\
\hline & & 1800 & $21.6 \pm 0.9 \mathrm{~h}$ & + & ND & + & $2.0 \pm 0.06 \mathrm{~h}$ & $0.8 \pm 0.04 \mathrm{def}$ \\
\hline & & 200 & $34.8 \pm 0.9 \mathrm{e}$ & ++ & + & ++ & $1.9 \pm 0.07 \mathrm{~h}$ & $0.4 \pm 0.02 \mathrm{ghi}$ \\
\hline & Quizalofop- & 400 & $26.2 \pm 0.5 \mathrm{~g}$ & + & + & + & $1.4 \pm 0.04 \mathrm{i}$ & $0.3 \pm 0.02 \mathrm{hi}$ \\
\hline & & 600 & $17.0 \pm 0.9 \mathrm{j}$ & + & ND & + & $0.9 \pm 0.04 j$ & $0.2 \pm 0.01 \mathrm{i}$ \\
\hline \multirow{7}{*}{$\begin{array}{l}\text { Pseudomonas sp. } \\
\text { strain PS6 }\end{array}$} & Control & 0 & $51.4 \pm 1.2 \mathrm{a}$ & ++ & + & +++ & $5.5 \pm 0.5 \mathrm{a}$ & $1.3 \pm 0.1 b$ \\
\hline & Glyphosate & 600 & $45.7 \pm 3.1 \mathrm{~b}$ & + & + & ++ & $4.9 \pm 0.2 b$ & $1.1 \pm 0.06 \mathrm{bc}$ \\
\hline & & 1200 & $40.8 \pm 1 c$ & + & ND & ++ & $3.8 \pm 0.2 \mathrm{~d}$ & $1.1 \pm 0.005 \mathrm{bcd}$ \\
\hline & & 1800 & $32.9 \pm 1.4 \mathrm{e}$ & + & + & + & $3.0 \pm 0.1 \mathrm{e}$ & $0.9 \pm 0.07 \mathrm{cdef}$ \\
\hline & Quizalofop- & 200 & $33.9 \pm 0.9 \mathrm{e}$ & ++ & + & + & $3.7 \pm 0.1 \mathrm{~d}$ & $1 \pm 0.1 \mathrm{cde}$ \\
\hline & & 400 & $23.3 \pm 1.5 \mathrm{~h}$ & + & + & + & $2.6 \pm 0.1 \mathrm{fg}$ & $0.7 \pm 0.04 \mathrm{efg}$ \\
\hline & & 600 & $12.8 \pm 1 \mathrm{k}$ & + & ND & + & $1.6 \pm 0.2 \mathrm{i}$ & $0.2 \pm 0.04 \mathrm{hi}$ \\
\hline LSD & & & 1.9569 & - & - & - & 0.05182 & 0.02890 \\
\hline
\end{tabular}

Values are mean of three replicates where each replicate constituted three plants pot $^{-1}$. Mean values followed by different letters are significantly different within a row or column at $p \leq 0.05$ according to DMR test following twoway ANOVA 
Table.4 Effect of Bradyrhizobium sp. (Vigna) R5 and Pseudomonas sp. PS6 bio- inoculants on chemical and biological properties of greengram raised in sandy clay loam soil treated with three concentrations of herbicides

\begin{tabular}{|c|c|c|c|c|c|c|c|c|c|c|c|}
\hline \multirow[t]{2}{*}{ Treatment } & \multirow{2}{*}{$\begin{array}{l}\text { Dose } \\
\text { rate } \\
(\mu \mathrm{g} / \mathrm{kg})\end{array}$} & \multirow[t]{2}{*}{$\begin{array}{l}\% \text { seed } \\
\text { germination }\end{array}$} & \multicolumn{3}{|c|}{ Symbiotic attributes } & \multicolumn{2}{|c|}{ Plant height (cm) } & \multicolumn{2}{|c|}{ Fresh weight (gm) } & \multicolumn{2}{|c|}{$\begin{array}{l}\text { Dry biomass } \\
(\mathrm{gm})\end{array}$} \\
\hline & & & $\begin{array}{l}\text { Nodule } \\
\text { number/plant }\end{array}$ & $\begin{array}{l}\text { Nodule } \\
\text { fresh weight } \\
(\mathrm{mg})\end{array}$ & $\begin{array}{l}\text { Dry } \\
\text { biomass } \\
(\mathrm{mg})\end{array}$ & Root & Shoot & Root & Shoot & Root & Shoot \\
\hline Uninoculated Control & 0 & 100 & 10 & $125 \mathrm{~b}$ & $44 \mathrm{~b}$ & $7.8 \mathrm{a}$ & $25.7 \mathrm{a}$ & $0.47 \mathrm{c}$ & $1.33 \mathrm{f}$ & $0.16 \mathrm{~b}$ & $0.7 \mathrm{~b}$ \\
\hline $\mathbf{G}(\mathbf{1 X})$ & 1444 & 90 & 9 & $111 \mathrm{e}$ & $35 f g$ & $7.0 \mathrm{bcd}$ & $19 b$ & $0.21 \mathrm{e}$ & $1.1 \mathrm{~g}$ & $0.1 \mathrm{efg}$ & $0.6 \mathrm{~d}$ \\
\hline $\mathbf{G}(2 \mathbf{X})$ & 2888 & 90 & 8 & $91.3 \mathrm{~g}$ & $29.3 \mathrm{ij}$ & $6.2 \mathrm{efg}$ & $18.7 \mathrm{~cd}$ & $0.10 \mathrm{~h}$ & $0.6 \mathrm{j}$ & $0.06 \mathrm{hi}$ & $0.3 \mathrm{i}$ \\
\hline $\mathbf{G}(\mathbf{3 X})$ & 4332 & 70 & 6 & $70 \mathrm{i}$ & $251 \mathrm{~m}$ & $5.07 \mathrm{hi}$ & 15.9def & $0.07 \mathrm{i}$ & $0.4 \mathrm{k}$ & $0.04 \mathrm{ij}$ & $0.2 \mathrm{j}$ \\
\hline $\mathbf{Q}(\mathbf{1 X})$ & 40 & 90 & 9 & $111 \mathrm{e}$ & $40 \mathrm{~cd}$ & $7.6 a b$ & $18.7 \mathrm{c}$ & $0.42 \mathrm{a}$ & $1.3 \mathrm{f}$ & $0.12 \mathrm{de}$ & $0.8 \mathrm{ab}$ \\
\hline $\mathbf{Q}(2 \mathbf{X})$ & 80 & 80 & 8 & $90 \mathrm{~g}$ & $40 \mathrm{~cd}$ & $6.1 \mathrm{efg}$ & $16.1 \mathrm{de}$ & $0.34 \mathrm{~b}$ & $0.8 \mathrm{~h}$ & $0.10 \mathrm{efg}$ & $0.5 \mathrm{f}$ \\
\hline $\mathbf{Q}(3 \mathbf{X})$ & 120 & 80 & 5 & $81 \mathrm{~h}$ & $24 m$ & $4.1 \mathrm{j}$ & $15.4 \mathrm{a}$ & $0.20 \mathrm{ef}$ & $0.7 \mathrm{i}$ & $0.06 \mathrm{hi}$ & $0.4 \mathrm{~h}$ \\
\hline $\begin{array}{l}\text { Bio inoculant } \\
\text { Bradyrhizobium sp. R5 }\end{array}$ & 0 & 100 & 12 & $148 \mathrm{a}$ & $54.6 \mathrm{a}$ & $7.5 \mathrm{ab}$ & $23 b$ & $0.33 b$ & $1.7 \mathrm{c}$ & $0.17 b$ & $0.8 \mathrm{a}$ \\
\hline G $(\mathbf{1 X})+R 5$ & 1444 & 90 & 10 & $146 \mathrm{a}$ & $53 \mathrm{a}$ & $6.2 \mathrm{efg}$ & $22.7 \mathrm{~cd}$ & $0.23 \mathrm{de}$ & $1.5 \mathrm{e}$ & 0.13 & $0.8 \mathrm{~b}$ \\
\hline$G(2 X)+R 5$ & 2888 & 80 & 10 & $121 \mathrm{~b}$ & $38.6 \mathrm{cde}$ & $5.05 \mathrm{hi}$ & $13.1 \mathrm{f}$ & $0.12 \mathrm{~h}$ & $1.08 \mathrm{~g}$ & $0.11 \mathrm{def}$ & $0.7 \mathrm{c}$ \\
\hline$G(3 X)+R 5$ & 4332 & 70 & 8 & $110 \mathrm{e}$ & $33 \mathrm{gh}$ & $4.4 \mathrm{ij}$ & $22.4 b$ & $0.09 \mathrm{hi}$ & $0.8 \mathrm{~h}$ & $0.09 \mathrm{fg}$ & $0.5 \mathrm{fg}$ \\
\hline$Q(1 X)+R 5$ & 40 & 90 & 8 & $114 \mathrm{~cd}$ & $36.3 \mathrm{ef}$ & $6.04 \mathrm{efg}$ & $20.3 b c$ & $0.28 \mathrm{c}$ & $1.6 \mathrm{~d}$ & $0.03 \mathrm{j}$ & $0.6 \mathrm{de}$ \\
\hline$Q(2 X)+R 5$ & 80 & 80 & 7 & $92 \mathrm{~g}$ & $28.3 \mathrm{jk}$ & $7.6 \mathrm{~b}$ & $18.6 \mathrm{~cd}$ & $0.26 \mathrm{~cd}$ & $1.3 \mathrm{f}$ & $0.13 \mathrm{~d}$ & $0.5 \mathrm{ef}$ \\
\hline $\mathbf{Q}(\mathbf{3 X})+\mathbf{R 5}$ & 120 & 80 & 6 & $82.3 \mathrm{~h}$ & $23.6 \mathrm{~m}$ & $6.0 \mathrm{efg}$ & $21.9 \mathrm{bc}$ & $0.18 f g$ & $0.9 \mathrm{~h}$ & $0.10 \mathrm{ef}$ & $0.4 \mathrm{~h}$ \\
\hline $\begin{array}{r}\text { Bio inoculant } \\
\text { Pseudomonas sp. PS6 }\end{array}$ & 0 & 90 & 10 & $116 \mathrm{c}$ & $41 \mathrm{c}$ & $7.7 \mathrm{a}$ & $21.6 b$ & $0.32 \mathrm{~b}$ & $1.9 \mathrm{~b}$ & $0.22 \mathrm{a}$ & $0.8 \mathrm{ab}$ \\
\hline G $(1 \mathrm{X})+\mathrm{PS} 6$ & 1444 & 90 & 9 & $113 \mathrm{cde}$ & $37.5 \mathrm{def}$ & $7.2 \mathrm{ab}$ & $15.6 \mathrm{def}$ & $0.28 \mathrm{c}$ & $1.4 \mathrm{e}$ & $0.09 \mathrm{gh}$ & $0.7 \mathrm{c}$ \\
\hline$G(2 X)+P S 6$ & 2888 & 90 & 7 & $97 \mathrm{f}$ & $35.3 \mathrm{fg}$ & $6.6 \mathrm{cde}$ & $12.9 \mathrm{f}$ & $0.22 \mathrm{e}$ & $1.3 \mathrm{f}$ & $0.07 \mathrm{~h}$ & $0.4 \mathrm{gh}$ \\
\hline G(3X)+PS6 & 4332 & 70 & 6 & $78.3 \mathrm{~h}$ & $27.3 \mathrm{jkl}$ & $5.7 \mathrm{gh}$ & $10 f g$ & $0.16 \mathrm{~g}$ & $0.8 \mathrm{f}$ & $0.14 \mathrm{~cd}$ & $0.3 \mathrm{i}$ \\
\hline$Q(1 X)+P S 6$ & 40 & 80 & 7 & $90.3 \mathrm{~g}$ & $321 \mathrm{hi}$ & $6.5 \mathrm{def}$ & $21.7 \mathrm{bc}$ & $0.28 \mathrm{c}$ & $2.06 \mathrm{a}$ & $0.09 \mathrm{gh}$ & $0.7 \mathrm{c}$ \\
\hline $\mathbf{Q}(2 \mathrm{X})+\mathbf{P S} 6$ & 80 & 80 & 6 & $78 \mathrm{~h}$ & $28 \mathrm{jk}$ & $5.8 \mathrm{fg}$ & $17.8 \mathrm{~d}$ & $0.20 \mathrm{ef}$ & $1.7 \mathrm{c}$ & $0.07 \mathrm{~h}$ & $0.7 \mathrm{c}$ \\
\hline$Q(3 x)+P S 6$ & 120 & 70 & 4 & $70 \mathrm{i}$ & $25.6 \mathrm{klm}$ & $4.1 \mathrm{j}$ & $12.9 f$ & $011 \mathrm{~h}$ & $0.7 \mathrm{i}$ & $0.04 \mathrm{j}$ & $0.2 \mathrm{i}$ \\
\hline LSD & & & & 4.07 & 2.45 & 1.08 & 2.57 & 0.03 & 0.08 & 0.02 & 0.05 \\
\hline F value & & & & 348.4 & 86.3 & 1.0 & 0.9 & 3.9 & 547.2 & 8.0 & 61.2 \\
\hline Inoculation $(\mathrm{df}=3)$ & & & & & & & & & & & \\
\hline Herbicides $(\mathrm{df}=1)$ & & & & 1075.6 & 233.5 & 67.1 & 53.4 & 178.3 & 610.9 & 33.4 & 283.1 \\
\hline
\end{tabular}

Each value is a mean of three replicate where each replicate constituted three plants/pot. Mean values are significant at $\mathrm{p} \leq 0.05$. Means followed by similar alphabets not significantly different from each other according to DMRT test. 
Fig.1 Scanning electron micrographs of Pseudomonas sp. strain PS6 (A) control cells, and treated with (B) $1200 \mu \mathrm{g} / \mathrm{ml}$ glyphosate and $400 \mu \mathrm{g} / \mathrm{ml}$ quizalofop. Bradyrhizobium sp. strain R5

(D) control cells (E) treated with $1200 \mu \mathrm{g} / \mathrm{ml}$ glyphosate and (F) treated with $400 \mu \mathrm{g} / \mathrm{ml}$ quizalofop. The area encircled indicates damage/rupture caused by the herbicides
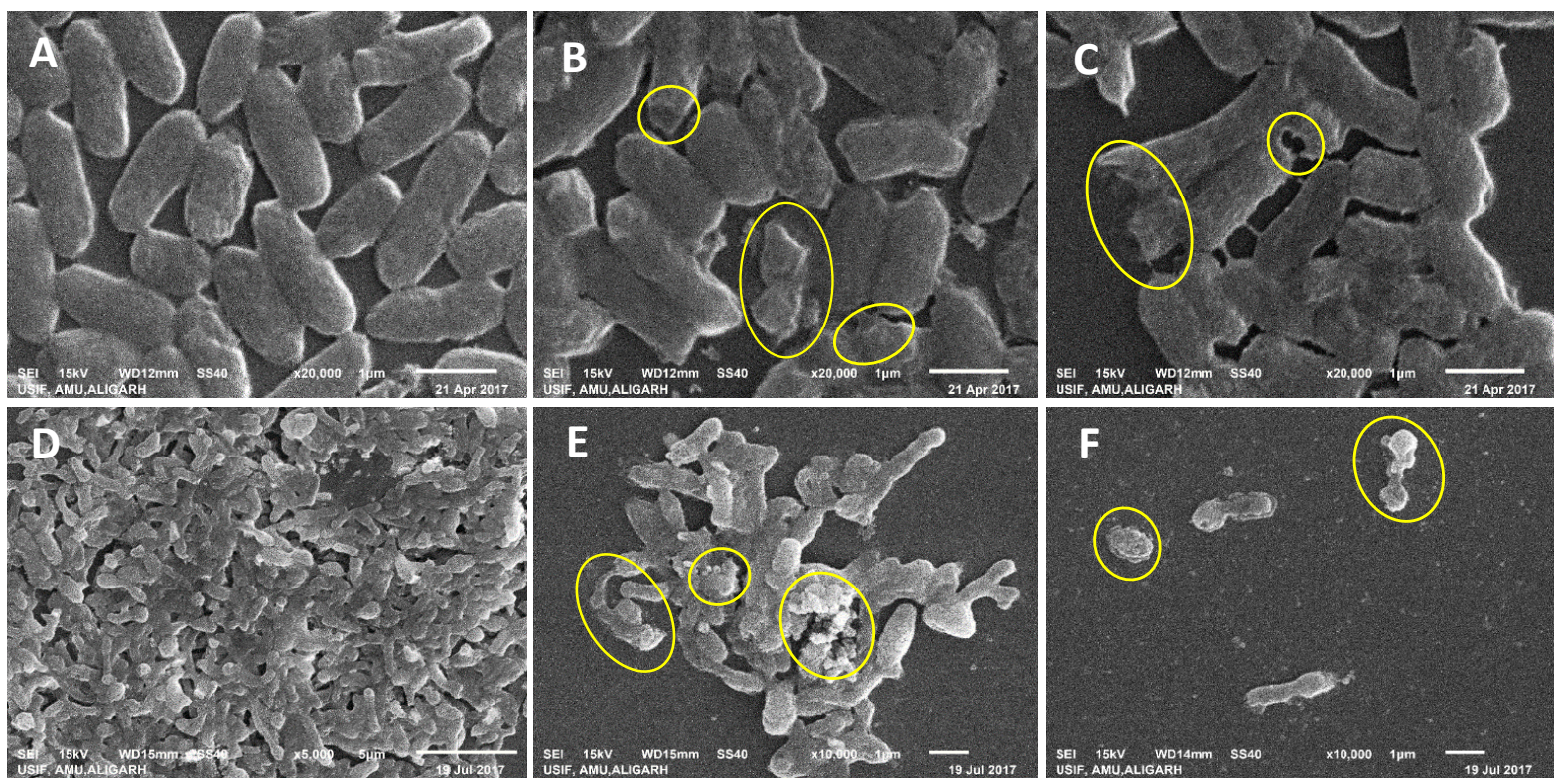

Fig.2 Inhibitory effect of herbicides glyphosate and quizalofop on EPS production by bacterial strain R5 and PS6

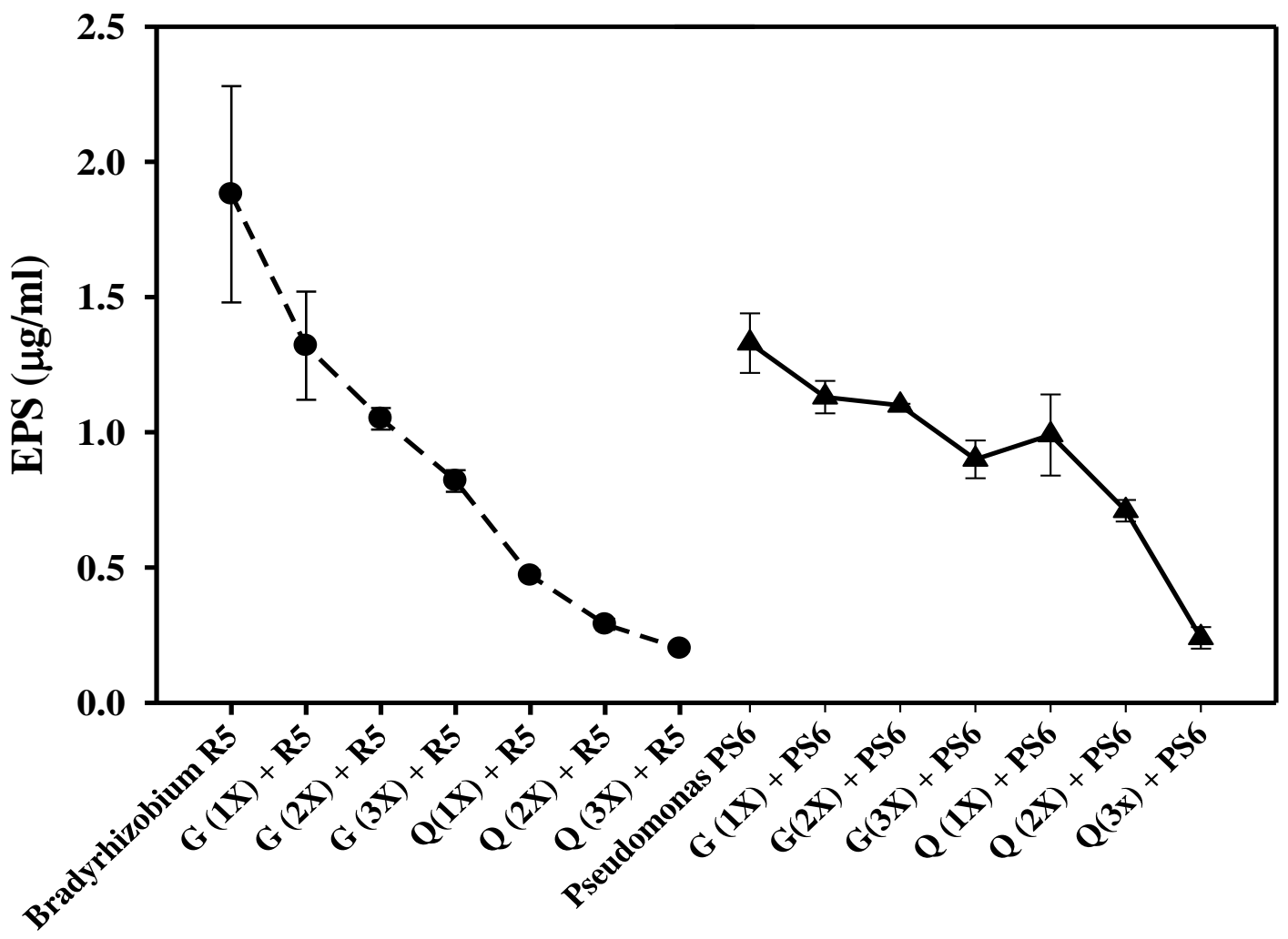


Fig.3 Chlorophyll content in fresh foliage of greengram plants grown in presence of glyphosate and quizalofop and herbicide tolerant bacterial strains (R5 and PS6)

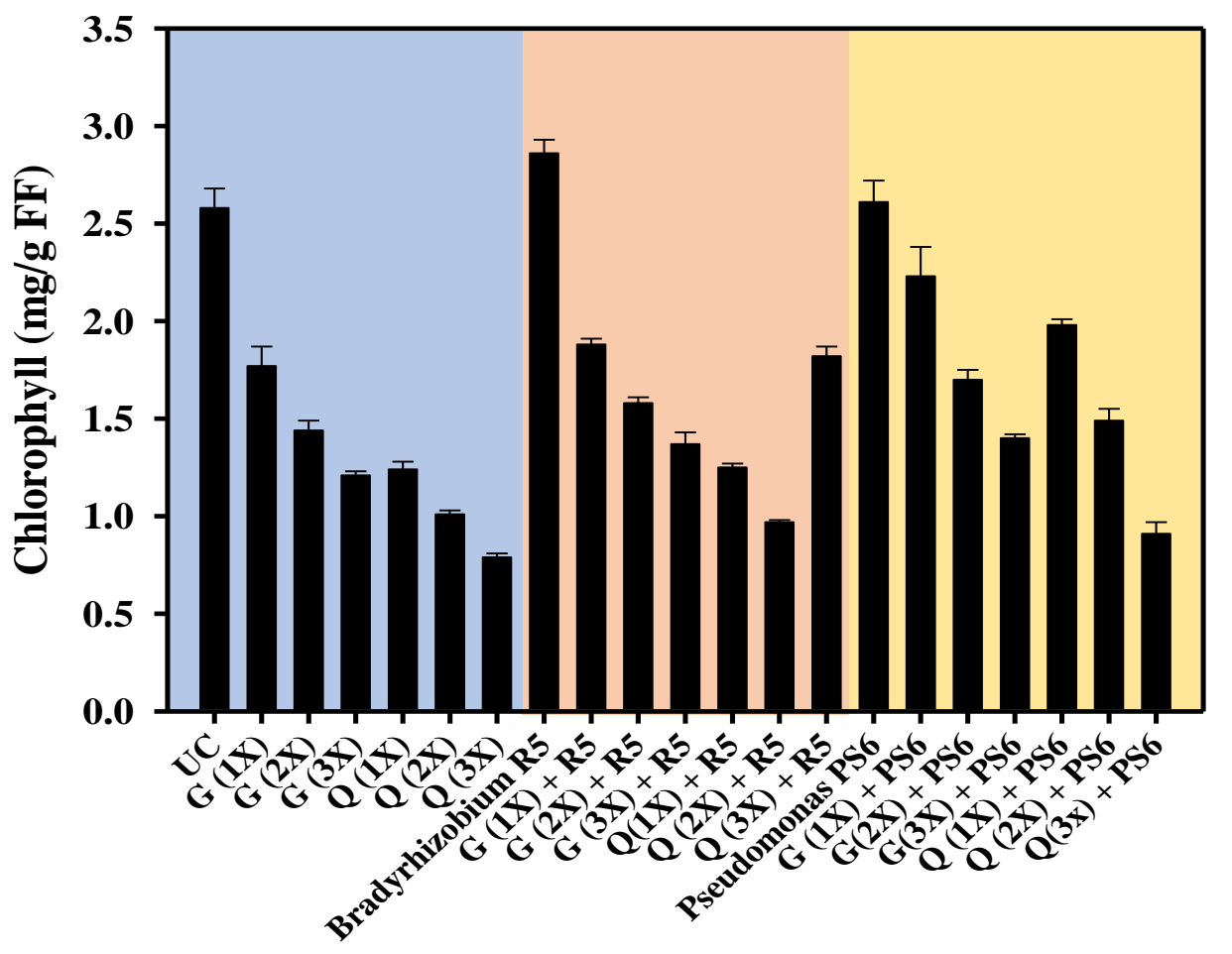

Fig.4 Scanning electron micrograph of greengram roots. Panel A shows root tip of greengram grown without herbicide whereas, panel B and C indicate root morphology altered by glyphosate and quizalofop, respectively
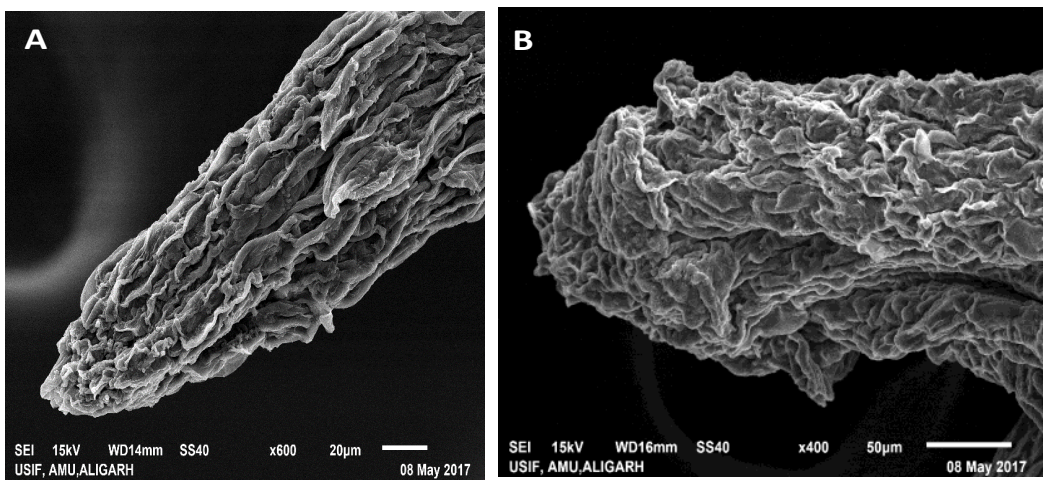

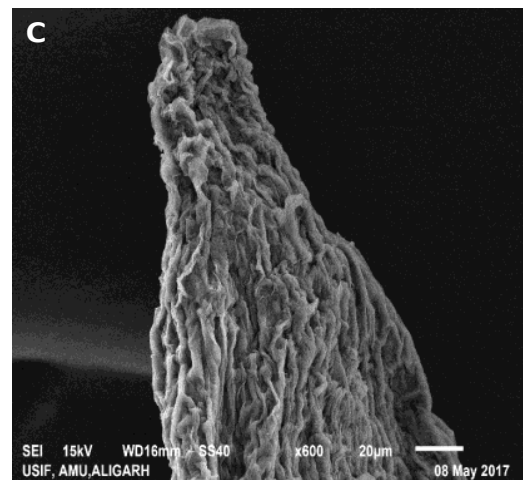

Effect of herbicides on chlorophyll content and symbiotic attributes

The impact of three concentrations of glyphosate and quizalofop on photosynthetic pigments (chlorophyll content) of fresh leaves of greengram measured at pod fill stage (60
DAS) was variable (Fig. 3). The total chlorophyll content however, consistently declined with increasing rates of herbicides irrespective of inoculant application. For example, the $120 \mu \mathrm{g} / \mathrm{kg}$ soil of quizalofop decreased the chlorophyll content by $80 \%$ over control as compared to control. In 
addition, when herbicide tolerant inocula (R5 and PS6 strains) were applied with three concentrations of herbicides, the chlorophyll content was increased as compare to greengram plants developed in soils treated with only herbicides. The chlorophyll content in fresh foliage of Pseudomonas sp. strain PS6 inoculated greengram plants increased by $46 \%$ at $2 \mathrm{X}$ concentration of quizalofop as compared to un inoculated plants grown solely with $2 \mathrm{X}$ concentration of quizalofop. Similarly, glyphosate, followed a trend like those observed for quizalofop. When Bradyrhizobium sp. strain R5 was used as bio inoculant, it increased the chlorophyll content maximally by $23 \%$, at normal rates of glyphosate.

The inoculated and un-inoculated greengram plants exposed to three concentrations each of quizalofop $\mathrm{P}$ ethyl and glyphosate had variable symbiotic properties. As an example, glyphosate at normal rate decreased the nodule number and nodule dry mass by $10 \%$ and $20 \%$, respectively, compared with the uninoculated and untreated control (Table 4). The bio-inoculant Bradyrhizobium strain R5 on the contrary, increased the nodule number and nodule dry mass by $10 \%$ and $33 \%$, respectively, compared with the plants grown in soil treated only with glyphosate (1X dose). A similar trend was observed for Pseudomonas strain PS6. Moreover, it was interesting to note that the rhizobacterial inoculants substantially increased the nodule number and dry mass nodule recovered from root systems of plants grown even with $3 \mathrm{X}$ doses of glyphosate and quizalofop-p-ethyl (Table 4).

\section{Morphological distortion in greengram roots}

Distortion/damage to root tips was observed under SEM when greengram plants were raised in the presence of 1200 and $400 \mu \mathrm{g} \mathrm{ml}^{-1}$ of glyphosate and quizalofop, respectively
(Fig. 4A, B and C). The inhibitory effect induced by both the herbicides was more distinct in the radical regions of growing roots. The destruction to root morphology of greengram plants grown under herbicide stress and observed under SEM is perhaps the first report by us in this study. However, a significant damage in the morphological structure of chickpea roots grown in the stressed condition is reported by Mondal et al., (2013). Similar structural damage in roots of wheat plants grown in metal treated soils has been reported (Rizvi and Khan, 2017).

In conclusion, the inhibitory effects of glyphosate and quizalofop on survival, cellular morphology and growth regulators synthesizing ability of Bradyrhizobium sp. R5 and Pseudomonas sp. PS6 differed significantly. Interestingly, the ability of both rhizobacterial strains to excrete plant growth facilitators was not completely lost even when they were exposed to higher concentrations of herbicides; however, the quantum of secretion declined progressively.

Additionally, the inhibitory impact of glyphosate and quizalofop on greengram plants was reduced substantially when both Bradyrhizobium sp. R5 and Pseudomonas sp. PS6 were used as inoculants against greengram crops. The inclusive enhancement in greengram production due to inoculation of strains R5 and PS6 even in the presence of glyphosate and quizalofop could probably be due to multiple reasons such as-(i) capability of rhizobacterial strains to tolerate higher concentrations of herbicides (ii) secretion of phytohormone, siderophores and exopolysaccharides by bacterial strains (iii) bio reduction of herbicides by herbicide tolerant rhizobacteria. Due to these multiple properties, the herbicide tolerant PGPR strains can be promoted as biofertilizer for accelerating the production of greengram even under herbicide enriched soils. 


\section{Abbreviations}

MIC- Minimum inhibitory concentration; IAA- Indole-3-acetic acid; HCN- Hydrogen cyanide; DAS- Days after sowing

\section{Acknowledgement}

The author (MS) is highly thankful to the Department of Agricultural Microbiology for providing all the facilities to complete this study.

\section{References}

Ahmed, B., Dwivedi, S., Abdin, M.Z., Azam, A., Al-Shaeri, M., Khan, M.S., Saquib Q., Al-Khedhairy A.A. and Musarrat, J. 2017. Mitochondrial and Chromosomal Damage Induced by Oxidative Stress in $\mathrm{Zn}^{2+}$ Ions, ZnO-Bulk and ZnO-NPs treated Allium cepa roots. Scientific Reports. 7: 40685. DOI: $10.1038 /$ srep40685.

Akbar, S. and Sultan, S. 2016. Soil bacteria showing a potential of chlorpyrifos degradation and plant growth enhancement. Brazilian $J$ Microbiol. 47(3): 563-570.

Alori, E.T., Glick, B.R. and Babalola, O.O. 2017. Microbial Phosphorus Solubilization and Its Potential for Use in Sustainable Agriculture. Frontiers in Microbiology, 8 .

Arnon, D.I., 1949. Copper enzymes in isolated chloroplasts. Polyphenoloxidase in Beta vulgaris. Plant Physiol, 24(1), 1.

Azarmi, F., Mozafari, V., Dahaji, P.A. and Hamidpour, M. 2016. Biochemical, physiological and antioxidant enzymatic activity responses of pistachio seedlings treated with plant growth promoting rhizobacteria and $\mathrm{Zn}$ to salinity stress. Acta physiolplantarum, 38(1), 21.

Aziz, O.A., Helal, G.A., Galal, Y.G.M. and Rofaida, A.K.S. 2016. Fungal Siderophores Production in Vitro as Affected by Some Abiotic Factors. Int. J. Curr. Microbiol. App. Sci, 5(6), 210-222.
Azubuike, C.C., Chikere, C.B. and Okpokwasili, G.C. 2016. Bioremediation techniques-classification based on site of application: principles, advantages, limitations and prospects. World $J$ Microbiol. Biotechnol, 32(11), 180.

Bakker, A.W., Schipper, B. 1987 Microbial cyanide production in the rhizosphere in relation to potato yield reduction and Pseudomonas spp. mediated plant growth stimulation. Soil BiolBiochem, 19: 451457.

Bellinaso, M.D.L., Greer, C.W., Peralba, M.D.C., Henriques, J.A.P. and Gaylarde, C.C., 2003. Biodegradation of the herbicide trifluralin by bacteria isolated from soil. FEMS Miocrobiol. Ecol, 43(2), 191-194.

Brick, J. M., Bostock, R. M., Silverstone, S.E. 1991. Rapid in situ assay for indole acetic acid production by bacteria immobilized on inter cellulose membrane. Appl Environ Microbiol., 57: 535-538.

Chandra, P.B., Ingle, R.W. and Tetali, S. 2016. Compatibility of Phosphate solubilizing microorganisms with different agrochemicals.

Curutiu, C., Lazar, V. and Chifiriuc, M.C. 2017. Pesticides and antimicrobial resistance: From environmental compartments to animal and human infections. New Pesticides and Soil Sensors, Pp. 373.

Deinum, E.E., Kohlen, W. and Geurts, R. 2016. Quantitative modelling of legume root nodule primordium induction by a diffusive signal of epidermal origin that inhibits auxin efflux. BMC Plant Biol, 16(1), 254.

Dye, D.W. 1962. The inadequacy of usual determinative test for the identification Xanthomonas sp. Newzeland J Sci, 5: 393-416.

Egamberdieva, D., Wirth, S., Li, L., Abd Allah, E.F. and Lindström, K. 2017. Microbial cooperation in the rhizosphere improves liquor ice growth under salt stress. Bioengineered, Pp. 1-6.

Gao, Z., Zhang, B., Liu, H., Han, J. and Zhang, Y. 2017. Identification of endophytic 
Bacillus velezensis ZSY-1 strain and antifungal activity of its volatile compounds against Alternaria solani and Botrytis cinerea. Biological Control, 105, 27-39.

Gordon, S and Weber, R.P. 1951. The colorimetric estimation of IAA, Plant Physiol. 26: 192-195.

Gupta, A.K., Kumar, B.S. and Shobha, B. 2017. Herbicidal effect of imazethapyr and its ready-mix with imazemox on yield parameters of greengram (Vigna radiata L.). IJCS, 5(4), 814-817.

Herman, P.L., Behrens, M., Chakraborty, S., Chrastil, B.M., Barycki, J. and Weeks, D.P. 2005. A three-component dicamba O-demethylase from Pseudomonas maltophilia, strain DI-6 gene isolation, characterization, and heterologous expression. Journal Bio Chemi, 280: (26), 24759-24767

Jaiswal, D.K., Verma, J.P. and Yadav, J. 2017. Microbe Induced Degradation of Pesticides in Agricultural Soils. In Microbe-Induced Degradation of Pesticides. Pp. 167-189.

Jiddimani, L. 2017. Sequential application of pre-and post-emergence herbicides against weeds in greengram (vigna radiata L.) (Doctoral dissertation, UASD).

Kandel, S.L., Firrincieli, A., Joubert, P.M., Okubara, P.A., Leston, N.D., McGeorge, K.M., Mugnozza, G.S., Harfouche, A., Kim, S.H. and Doty, S.L. 2017. An in vitro study of bio-control and plant growth promotion potential of Salicaceae endophytes. Frontiers Microbiol, 8.

Kaushal, M., Wani, S.P. 2016. Plant-growthpromoting rhizobacteria: drought stress alleviators to ameliorate crop production in drylands. Ann Microbiol., 66: 35-42.

Kurhade, K.C., Gade, R.M., Belkar, Y.K. and Chaitanya, B.H. 2016. Detecting tolerance in Pseudomonas fluorescens to pesticides. Agricultural Science Digest-A Research Journal, 36(3): 247-249.

Kurth, C., Kage, H. and Nett, M. 2016. Siderophores as molecular tools in medical and environmental applications. Organic Biomol Chem 14: 8212-8227.

Mody, B.R., Bindra, M.O., Modi, V.V.1989. Extracellular polysaccharides of cowpea rhizobia: compositional and functional studies. Arch Microbiol 1:2-5.

Mondal, N.K., Das, C., Roy, S., Datta, J.K. 2013. Effect of varying cadmium Stress on chickpea (Cicer arietinum L.) seedlings: An Ultrastructural study. An Environ. Sci. 7.

Neiland, J. B. 1981. Microbial iron compounds. Ann Rev Biochem, 50:715-731.

Nithyakalyani, V., Kannan, M., and Anandan, R. 2016. Insecticide and Salt Tolerance of Plant Growth Promoting Root Nodule Bacteria. Int J CurrMicrobiol App Sci 5(4), 942-956.

Ozkara, A., Aky1l, D. and Konuk, M. 2016. Pesticides, Environmental Pollution, and Health. In Environmental Health RiskHazardous Factors to Living Species. InTech.

Patel, K., Goswami, D., Dhandhukia, P., and Thakker, J. 2015. Techniques to study microbial phytohormones. In D.K. Maheshwari (Ed.), Bacterial metabolites in sustainable agroecosystem Springer International. Pp. 1-27.

Porte, D., 2017. Interactive effect of rhizosphere bacterial consortia on performance of chickpea (Doctoral dissertation, Indira Gandhi Krishi Vishwavidhyalaya, Raipur).

Prashar, P. and Shah, S. 2016. Impact of Fertilizers and Pesticides on Soil Microflora in Agriculture. In Sustainable Agriculture Reviews. Pp. 331-361

Premachandra, D., Hudek, L. and Brau, L. 2016. Bacterial Modes of Action for Enhancing of Plant Growth. J Biotechnol Biomater, 6(236), 2.

Rani, R., Kumar, V., 2017. Endranaosulfan Degradation by Selected Strains of Plant Growth Promoting Rhizobacteria. Bul. Environ. Contam. Toxicol. 99(1): 138145.

Rijavec, T., and Lapanje, A. 2016. Hydrogen cyanide in the rhizosphere: not 
suppressing plant pathogens, but rather regulating availability of phosphate. Frontiers in Microbiology, 7:1785.

Rizvi, A. and Khan, M.S. 2017. Biotoxic impact of heavy metals on growth, oxidative stress and morphological changes in root structure of wheat (Triticum aestivum L.) and stress alleviation by Pseudomonas aeruginosa strain CPSB1. Chemosphere, 185, 942-95.

Saleem, S., Ahmed, B., Khan, M.S., Al-Shaeri, M. and Musarrat, J. 2017. Inhibition of growth and biofilm formation of clinical bacterial isolates by $\mathrm{NiO}$ nanoparticles synthesized from Eucalyptus globulus plants. Microbial Path, 111, 375-387.

Sicairos, L. N., Zamudio A.U.A., de la Mireya Garza M, Jorge Velázquez-Román J, Héctor M, Flores-Villaseñor HM, Adrian Canizalez-Román A. 2015. Strategies of Vibrio parahaemolyticus to acquire nutritional iron during host colonization. Front Microbiol.

Somasegaran, P., Hoben, H.J. 1994 Handbook for rhizobia: methods in legume Rhizobium technology. Springer, New York.

Tang, D., Dong, Y., Ren, H., Li, L. and He, C. 2014. A review of phytochemistry, metabolite changes, and medicinal uses of the common food mung bean and its sprouts (Vigna radiata). Chemistry Cen J $8(1): 1$.

Thakur, D., Kaur, M. and Mishra, A. 2017. Isolation and screening of plant growth promoting Bacillus spp. and Pseudomonas spp. and their effect on growth, rhizospheric population and phosphorous concentration of Aloe vera. J MedPlants, 5(1),187-192.

Tripti, Kumar, A., Kumar, V. and Anshumali, 2015. Effect of commercial pesticides on plant growth-promoting activities of Burkholderia sp. strain L2 isolated from rhizosphere of Lycopersicon esculentum cultivated in agricultural soil. Toxicol Environ Chemis, 97(9), 1180-1189.

Usman, S.,Kundiri, A.M. and Nzamouhe, M. 2017. J EcolToxicol.

Zaller, J.G., König, N., Tiefenbacher, A., Muraoka, Y., Querner, P., Ratzenböck, A., Bonkowski, M. and Koller, R. 2016. Pesticide seed dressings can affect the activity of various soil organisms and reduce decomposition of plant material. BMC Ecol., 16(1), 3.

\section{How to cite this article:}

Mohammad Shahid and Mohammad Saghir Khan. 2017. Assessment of Glyphosate and Quizalofop Mediated Toxicity to Greengram [Vigna radiata (L.) Wilczek], Stress Abatement and Growth Promotion by Herbicide Tolerant Bradyrhizobium and Pseudomonas species. Int.J.Curr.Microbiol.App.Sci. 6(12): 3001-3016. doi: https://doi.org/10.20546/ijcmas.2017.612.351 